Philosophy and Progress: Vols. LIX-LX, January-June, July-December, 2016 ISSN 1607-2278 (Print), DOI : http://dx.doi.org/10.3329/pp.v59i1-2.36679

\section{REVISITING THE CONCEPT OF HUMAN SECURITY}

\section{Mohammad Kamrul Ahsan*}

The paper attempts to tackle different approaches to security. The investigation expounds how, as opposed to the conventional and new realists' approaches to security, the approach to human security seems less inadequate. Here I defend the view that the wider understanding of human security, which involves and envisages security issues such as security from 'want' and 'fear', and also which amounts to sustainable security, offers much to the field of sustainable development. By justifying the UN as the legitimate actor to deal with global conflicts and security, recognizing interrelated significant components of human security, as expressed in the 1994 UNDP report, as well as recognizing all bearers of intrinsic value as referents of security, the human security view justifies its operationalization and satisfactorily underlies the three major pillars of sustainable development: economic,

\footnotetext{
* Professor, Department of Philosophy, Jahangirnagar University E-mail : kamrul1353@gmail.com
}

social and environmental sustainability. This entails that it is hardly possible to attain the key objective of sustainable development, a sustainable future, while disregarding the security view in its wider sense (i.e., human security view).

\section{I}

The concept 'security' did not appear in the literatures of relevant policy fields until the 1940s. At the beginning of its use, the meaning of security was restricted to the military defence of a state's territory, which continued for a period of nearly three decades - from the 1940s until the 1960s. This stance is familiar as the conventional (or traditional, or classical, or orthodox) realists ${ }^{1}$ approach to security. A change occurred in the scope and meaning of security for the first time in the 1960s. The understanding that economic power, diplomatic capability or ownership of a key economic resource (e.g. oil) is pertinent in defining security has brought about this change. This stance is familiar in the discipline of International Relations as ‘Neo-realism' which:

maintained the focus on states and the pursuit of power but accepted that not everything that happens in the world is determined by military might. (Hough, 2004, p. 4)

A further transformation of the meaning of security occurred in the post-Cold War world. This has been initiated and advanced by scholars who were not convinced that 'Neorealism' had evolved far enough from Realism to take account of the changes that had occurred in the world since the 1940s.' (Ibid.) This is recognised as the 'human security view' of security.

Criticising the Neo-realists' stance, the proponents of the human security view state that, although Neo-realists recognise 
issues, such as 'economic power', 'diplomatic capability' and 'ownership of a key resource or resources' as important issues in defining security, they have entirely omitted (or failed to address) a very crucial issue, i.e. humans' security. Another objection that could be put forward against Neo-realists is that they consider security as merely materialistic (as opposed to personal security, freedom from crime, oppression, violence etc., which concerns the access to materials to address purely military and economic capability). The same objection can be put against the conventional realist approach to security. These limitations with both conventional and Neo-realist definitions of security, as has been argued by Erdogan, justify a fresh interpretation of security. (Erdogan, 2009, p. 1) It is in this context that the 'human security view' arose.

The 1994 Human Development Report of the UNDP focused on the 'human security' issue for the first time as a major statement. To begin with this report, the author rejects the realists' approaches to security (both conventional and Neo-realist stances) on the ground that realists' approaches to security have omitted entirely 'non- military aspects of security', especially 'the legitimate concerns of the ordinary people who sought security in their daily lives', (UNDP, p. 2) or in other words 'the right to individual security'. The author then goes on to suggest that human beings are the central analytic referent of security, directing security to a new, broader horizon. Scholars in the relevant field of security now herald this as a paradigm shift, a journey from 'state' towards 'human' security.

A fundamental question may well arise here, that of whether the human security view is a complete rejection of the state-centred view. Here the answer is 'no', because the objection against the state-centred view (the realist's view) is not because of its advocacy for the territorial defence of states, but rather for its entire omission of non-military security issues, particularly human security concerns. Thus, rather than declaring them redundant, the proponents of the human security view see state-centred views as an inadequate or narrow conception of security and envisage their own view the human security view - as the more adequate approach, which is also known as the broader conception of security.

It thus appears overall that as a relatively new and developing view, the human security view, is interpreted in ways that involve contested conceptions, although the divides among the conceptions are not as clear as they might seem. For, despite its flexibility, human security has a common core, i.e. the issue of individual security, and various conceptions of human security share this core in common. This core has been accorded greater importance in international governance as well as in codes of conduct. In addition, it has turned into an academic trend and a fledgling policy movement in recent times.

Furthermore, most importantly, disagreements among the contesting conceptions or views do not merely concern the interpretation of human security; they are to a large part about its operationalisation as well. Among disagreements as to its operationalisation, some are more complex and stronger, and involve the issue of its analytical utility, political viability and ethical justification. (Svensson, 2007, pp. 3-10) Thus, further studies are needed to grapple more with the question of how to operationalise human security, and which conception or view of human security would be ethically more convincing and compatible, if not conclusive. The aim of this article is to revisit the concept of security focusing on its competing views as regards its interpretation and operationalization. 
Through tackling different approaches to security, it is assumed that it is hardly possible to attain a sustainable future, while disregarding the security view in its wider sense.

\section{II}

As has been mentioned in the paragraph above, a thorough study of human security, involving its interpretational and operational aspects, would involve at least three questions and require clear replies to those questions in order to address security challenges that are discussed under various security conceptions in the vibrant field of security studies. The questions are:

i) Security for whom?

ii) ii) Security from whom [or what]?

iii) Security by whom? (Jain, 2006, p. 341)

Those who believe in realist approaches to security (both the conventional and the Neo-realist approach) have an immediate answer to the first question: Security for whom? For them, security is concerned with states, i.e. securing states from external attacks. External attacks may come through military intervention by another country or through economic sanctions on essential survival goods or foods, or blocking of sea routes etc. Here the realist's conceptions of security are restricted to mean protection for sovereign states and individuals within the national boundaries of the nation states. This sense of security hardly recognises any responsibility of the state to the people who live within its territory for whatever reason, but are not citizens.

Nigel Dower, a prolific writer on this issue, considers this realist characterization and understanding of security as too narrow, and summarized their views on security as follows: (i) It [security] is about being free from arbitrary attack on one's person or property (from individuals in one's society, one's state, foreign states or international terrorists)... Its emphasis is upon the negative goal of reducing or eliminating the risk that bad things will happen to people.

(ii) In political terms its pursuit is on limited groups of people, namely the citizens of a state whose government pursues security. The focus of policies pursued by governments tends to be nationalist...

(iii) The chief guarantor is an effective state which protects its citizens through law and order, through effective external defence, and increasingly in the modern world by a range of measures to reduce the risk of terrorist attack.

(iv) Its focus is on the present and medium-term future.

(v) Its success depends on the general tendency of human agents not to violate the rights of other people whether through moral persuasion, the threat of sanctions or prevention. (Dower, 2005, p. 1)

This very sense of 'security' is centred on the 'territorial sovereignty' of a state. Here the focus is on military aspects of security, and the idea is that the state is the chief guarantor of protection; and armaments, threat of sanctions or prevention are the best strategic measures for security. Humans are treated here as citizens of the state, not as members of the human species, suggesting that the state has no responsibility to the people who are not citizens (e.g. overseas non-residents, foreign visitors and so forth) but live within the boundary of the state in question. 
Among the ethical issues arising here, some arise from the security issue, as thus defined or interpreted by the conventional realists and the neo-realists. The problems here are (1) whether states, not human beings, are the only eligible candidates for being selected as referents of security; if protection from security threats is a fundamental human right then the subsequent concern arises (2) whether 'it is more important morally that we stop other people doing wrong to other people than that we prevent or stop suffering which is caused by many other causes, such as natural causes, social injustice and other human causes.' (Dower, Security in the ...)

Here the important concern relating to the above mentioned ethical queries is 'human well-being', and both the realist approaches to security appear to be counterintuitive from the view point of well-being. In one sense, in terms of their being suitable as a subject matter for moral discussion, both the realist approaches are entirely unsuitable or amoral. In another sense, even if realist approaches are counted as a subject matter of moral judgment, they often fail to merit a positive verdict. The reason for this failure is the fact that the fulfillment of the realist project is often in conflict with human well-being, and being antithetical or neutral to human wellbeing, realist approaches to security warrant being envisaged as morally defective by any normative ethical theory, in the full range from egoism to altruism, and from consequentialism and virtue ethics to deontology.

Realist approaches themselves justify Nigel Dower's criticism through maintaining that the only referent of security is the state, and the source of the threat to security is merely external. Of observations against realist approaches, at least two are obvious: firstly, a much greater security threat comes from disease, poverty, hunger, environmental disasters and so forth, and secondly a greater threat may come from a state's own territory rather than from external countries.

Purnendra Jain elaborates on this understanding. Security threats, as he observes, can come from another state in the form of a war in which civilians are affected and relentlessly suffer. They may also come internally through political repression, a failing government, and bad governance, or through natural disasters, such as a tsunami or an earthquake. Security, therefore, involves individuals as its major concern, and the central purpose of security is protecting individuals from all attacks, both internal and external. (Jain, 2006, p. 342)

Jain's interpretation is penetrating, but not adequate. Anything that creates security threats justifies being tackled in the interpretation of human security. Every species, as ecologists inform us, has a certain role in the ecosystem if it is to run properly. Human life being part of nature depends on the proper functioning of the biosphere (which can, in other words, be assumed to be our life support system). Therefore a secured human life and its continued or sustainable existence is not possible with policy initiatives which do not appropriately focus on ecosystems and biodiversity (i.e. species) in their policy decisions. Given this, Jain's interpretation of human security seems to be inadequate. Another assumption that makes Jain's interpretation of human security vulnerable is the view that 'nonhuman life plausibly has intrinsic value as well as human life' (Atfield, 2004, p. 303). For Jain's interpretation does not involve concern for non-human creatures, the bearers of intrinsic value.

In light of this understanding, the answer to the first question: 'security for whom?' is thus to be the bearers of intrinsic value i.e., members of the human community and the community of non-human creatures. Furthermore, ecosystems 
and biodiversity warrant consideration for their role in supporting the survival of living creatures. For some ${ }^{2}$, 'nonliving parts of nature', for example, the systemic value of nature also has intrinsic value and thus can be candidates for the same (in some views such as that of Holmes Rolston, 1998, pp. 160-91). And this implies that referring security just to human beings, let alone to the state, is a narrow use of human security.

The second question is 'security from whom [or what]?' According to the realist view, the answer is: security from attack by other countries or other groups such as terrorists, or attacks by lawless individuals. Proponents of the human security view provide their answer by dividing the sources of security threats into two categories, namely 'security from want' and 'security from fear'. (Jain, 2006, p. 341) The first concern involves issues such as hunger, poverty, disease and natural disasters and the like. The latter concern involves issues such as security against violence, human rights abuse, civil war and ethnic conflicts and so forth.

While most of the leaders of the West and East, and international institutions such as the United Nations, all agree on the first kind, there is a difference of emphasis among proponents of the latter concern. The Andrew Mack report (supported by the Government of Canada and a range of other European countries) and the Ogata-Sen report (funded by the Japanese Government) could be mentioned here as testimony of the disagreement on the range of human security issues. The Mack report focuses much on the 'freedom from fear' aspect of the security issue, while the Ogata-Sen report puts less emphasis on it and much more on the 'security from want' aspect.
Here one thing is very clear, that, while the realist view of security entirely omits issues of security from 'want' and 'fear', proponents of the human security view (the wider conception of security) set them at the centre of security discourse. Now an ethical question arises whether human beings have a right to life and whether human beings have a right to improve the quality of their lives or, in other words, the right to development. Although the latter question needs interpretation, philosophers agree on the issue that human beings have a right to life. The cogency of humans' right to life speaks for itself. On the human right to development, there is apparent guidance from the United Nations. The UN 'Declaration on the Right to Development' of 1986 is an official recognition of development as a human right. ${ }^{3}$ Thus, in terms of the human right to life and development, and also from the point of view of ethical justification, the human security view merits recognition.

We can now turn to Mill's essay on Utilitarianism for further clarification on security, which is supportive of the human security view, but adverse to the realist approach to security. Mill regards security and liberty as the permanent or vital interests of a person. And about security he says it is a pre-condition of a valuable life. Human security and liberty ground people's moral rights. Thus, for Mill, actions that damage human security interests are not only harmful, but also promote injustice. As a general rule, Mill therefore suggests that moral requirements should be restricted to a prohibition of aggression and of injury to individual security and liberty. (Gray, 1979) Thus in light of Mill's analysis, the human security view seems to be the more plausible and morally sound view, and by contrast the realist approaches to security appear to be morally threadbare. 
'Security by whom?' is the third and most debatable question concerning security. The realist answer to this question is 'the state'. Hobbes might have an influence on the realists in this context. Hobbes, writing on the necessity of a Leviathan (a strong state), maintains that strong support from states is obviously needed in order to protect individual interests from the danger of anarchy that results from the general tendency of the individual's selfish interest. (Hough, 2004, pp. 2-3)

Hobbes' argument, however, does not seem to be strong enough because, when owing to economic adversity, some states are overrun through globalization and bad governance, the capability to provide protection has come into question. War-torn societies are the hot spots of state failure. One major concern here is the view that states themselves can be agents of human security violations. As Lloyd Axworthy puts it:

The state has, at times, come to be a major threat to its population's rights and welfare -- or has been incapable of restraining the warlords or paramilitaries -- rather than serving as the protector of its people. (Axworthy, 2001, p. 19)

Another major concern here is the fact that irrespective of political ideals and practices (whether democratic or nondemocratic) states could function as agents of security threats. For example, as has been stated by Jain, there are abuses of human rights in China and Myanmar, both authoritarian states. The same situation prevails in democratic and advanced states as well. Examples include a law of Australia under which police may indiscriminately search premises and facilities run by Muslim communities. Police are also authorized to interrogate and deport organizations/individuals suspected of preaching violence. (Jain, 2006, p. 343) These issues are said to have pervasively influenced the broadening of the focus of security discourse beyond the level of the state and towards individuals. Also these issues have accelerated the advent of global organizations (in the context of global security) for rescuing that part of humanity who are at risk of severe security threats.

Despite their disagreement on many other aspects, the Mack report and the Ogata-Sen report notably agree on the aptness of the United Nations as an appropriate (and incomparable) international institution for the protection of the security in question. Now the question is: Who and which agencies have the capacity and legitimacy to provide security from 'want' and 'fear'? Is the UN a legitimate body and capable of providing security in this regard? If so, which, among the United Nations Organizations and its agencies or other international organizations (such as the World Bank and the IMF), or international NGOs, or other organizations (such as NATO, OSCE etc.), is the best alternative to protect security (in its broad sense) in terms of legitimacy, capability and effect?

The international organizations which have a clearer mandate than most to prevent conflicts, in order to guarantee security and peace, are 'the UN and, within Europe, OSCE and NATO’ (Smith, 2003, p. 17). NATO (a military organization) and OSCE (the Organization for Security and Co-operation in Europe), however, act more like regional bodies, which do not represent one hundred per cent of the nation states across the world, as does the UN. As regional organizations (or international in the more limited sense) NATO and OSCE:

...may support global goals [of security]... but equally they may assert their collective interests against the interests of other countries of the world. (Dower, 1998, p. 181) 
Therefore, organizations such as NATO and OSCE cannot be treated as the legitimate actors to deal with global conflicts and security, though regional organizations, especially NATO, play a vital role in the present international security crisis, and have a considerable bearing on the present volatile global state of security, through employing strategic (military) solutions to all security challenges (in the traditional sense) irrespective of their nature, and, in turn, act more like a higher version of a mighty nation-state actor.

International multilateral financial institutions, such as the World Bank and the IMF, also have a major influence on economic development and security across the world. Their roles, in any case, are not beyond criticism. For example, the financial prescriptions of the IMF at the time of the Asian economic crisis in the 1990s have been highly controversial.

International NGOs are also concerned with global security issues and:

Increasingly act as lobby groups and as providers of expert information and advice, not merely to individual governments but also at international conferences and in international institutions. (Ibid., p. 184)

The effectiveness and legitimacy of international NGOs as global security actors, however, have come under attack. Cecilia Albin, one of the critics, argues that:

Despite the increased presence and activism of NGOs on the international stage, however, their participation in negotiating fora remains largely unofficial, ad hoc, or subjected to the preferences of national governments. A principled and cautious expansion of the opportunities for NGOs to participate in international negotiations could enhance the effectiveness and legitimacy of their outcomes. (Albin, 1999, p. 371)
Criticizing the legitimacy and effectiveness of NGOs as global security actors, Mohamed Jawhar Hassan argues that:

International NGO work driven by Western interests, values and world views sometimes do[sic] not jive with the more pressing and relevant needs of developing societies, e.g. emphasis on democracy and civil and political rights over stability, poverty eradication and good governance. (Hassan, 2008)

As can be observed here, Albin and Hassan plausibly claim that international NGOs, through being more unofficial in negotiating global security issues, and sometimes being more focused on world issues (such as democracy and civil and political rights), and also sometimes being less focused on the relevant needs of developing societies (e.g. poverty eradication and good governance), thus fail to emerge as effective and legitimate actors so as to tackle global security issues.

The UN, compared to other organizations mentioned above, can arguably be ranked as a global organization, in the true sense:

... whose stated aims are to facilitate cooperation in international law, international security, economic development, social progress and human rights issues. (XTimeline, 2008)

As the representative of the nation states (nearly all independent states throughout the world), the UN assumes the legitimacy of action to deal with international security issues. As Nigel Dower traces it:

The United Nations was set up at the end of the Second World War [in 1945]. Its primary purpose was to provide a realistic framework for maintaining international security. (Dower, 1998, p. 116) 
The rationale of the UN for managing human security and/or global security concerns is in any case at least implicit in the analysis of the two following issues: (1) the meaning of

human security, and (2) the membership policy of the UN (open to all nation states subject to the fulfillment of its requirements).

As has been mentioned earlier, threats to security are not only 'military' in nature (where solutions depend on the use of force). The human security view implies that threats to security can come from other areas as well, such as hunger, poverty, disease and natural disaster, human rights abuse, civil war and ethnic conflicts etc. Furthermore, the security threats that come from these sources cannot be faced by using military force, for there is no military solution to such insecurities. In addition to human beings, nonhuman life and human life support systems (ecosystems) are also vital issues in current security debates. For a loss of any species or any disorder in natural systems causes damage to all life forms including humans.

These wide-ranging security elements are also included in the subject matter of state sovereignty. Being global in nature they are a subject matter of inter-state policy initiatives, and therefore require global initiatives (legitimate and effective) in order to protect the biosphere, the only habitat of all lives on earth. Hence, security can be assumed, in its broad sense, to be addressed and achieved by a global international organization through balancing all the instruments of foreign policies of nation states and fostering the well-being of lives on earth, based on common policies, inter-state cooperation and agreements. The United Nations Organization, in this connection, is intended to be the exclusive legitimate actor, which can arguably address all aspects of diversified human security challenges, with a view to protecting human and other lives from all security threats all over the world.

The Brundtland Report of 1987, entitled Our Common Future, ascribes great importance to this matter, and a relevant passage reads as follows:

National boundaries have become so porous that traditional distinctions between local, national, and international issues have become blurred. Policies formerly considered to be exclusively matters of 'national concern' now have an impact on the ecological basis of other nations' development and survival. Conversely the growing reach of some nations' policies-- economic trade, monetary, and most sectoral policies -into the 'sovereign' territory of other nations limits the affected nations' options in devising national solutions to their own problems. This fast-changing context for national action has introduced new imperatives and new opportunities for international cooperation. (WCED, 1987, p. 312)

The Brundtland Report in this passage expressively divulges the necessity of increasing cooperation among the nation states in order to support secure and peaceful continued human existence throughout the world, for separate policies and institutions can no longer cope with the changing interstate security issues in question.

The report of the World Commission on Environment and Development, particularly its definition of sustainable development, also provides persuasive support for the UN's justifiability as a security actor. The Brundtland definition of sustainable development is grounded on socio-economic and environmental (notably non-anthropocentric) value concerns. Given this, the UN seems to hold a wider view concerning the value of the environment, which in turn seems to be supportive of issues of human security. 
Two other conventions, which were agreed in Rio in 1992, and which arguably further justify the role of the UN as equally legitimate and crucial, are the United Nations 'Convention on Biodiversity' and the 'Framework Convention on Climate Change'. The agreement embodying the Convention on Biodiversity (CBD) was adopted for the preservation of biodiversity all over the world, whilst another key agreement, the UN Framework Convention on Climate Change (UNFCCC), was adopted for the stabilization of greenhouse gas emissions into the atmosphere.

Current environmental challenges and humans' diversified security concerns justify the urgency and aptness of the agreements of the UNFCCC and the CBD. The need for those agreements has been reaffirmed in the United Nations' Copenhagen Climate Change Conference 2009 by participant countries signing the 'Copenhagen Accord' (although some people believe that by signing the Accord, poor and affected countries 'risk displacing the legitimate negotiation process taking place under the auspices of the $\mathrm{UN}^{4}$ ), and in the United Nations' 2002 Strategic Plan for the Convention on Biological Diversity (a strategic plan was adopted in an attempt to stop the loss of biodiversity and to secure the continuity of benefits that it provides through conservation and sustainable use of its elements, particularly genetic resources and a fair and equitable share of the benefits resulting therefrom). (CBD, 2012) Some scholars, however, argue that the result of implementation of the UNFCCC under the rules adopted in the Kyoto Protocol is incompatible with the objectives of CBD, because they involve threats to the lives of many other species. ${ }^{5}$

The other factor that vindicates the UN as the most distinctive international organization in protecting world humanity from security threats is its membership policy. As the UN charter outlines it:
Membership in the United Nations is open to all other peace-loving states [sc. other than the five permanent members of the Security Council] which accept the obligations contained in the present Charter and, in the judgment of the Organization, are able and willing to carry out these obligations. (Charter of the United Nations, Chapter 2, Article 4.)

In terms of the number of member states, the UN is the largest international organization:

With the addition of Montenegro on 28 June 2006, there are 192 United Nations member states, including virtually all internationally-recognized independent states. (Ibid.)

The large membership of the UN, undoubtedly, proves its role to be truly global.

\section{III}

A question now arises here: has the UN been successful in achieving its professed goal? Indeed, the achievement of the UN is mixed. Not all its aims have been fully realized. It has had both success and failure in world security issues. Remarkable successes following the end of the Cold War include:

- a 40\% drop in violent conflict[ since the early 1990s];

- an $80 \%$ drop in the most deadly conflicts [since roughly the middle of the 1990s] and an 80\% drop in genocide and politicide [between 1998 and 2001]. (Human Security Centre, 2006)

On the other hand, some notable failures of the UN in security issues include: 
- Failure to prevent the 1994 Rwandan genocide, which resulted in the killings of nearly a million people, due to the refusal of Security Council members to approve any military action.

- Failure by MONUC (UNSC Resolution 1291) to effectively intervene during the Second Congo War, which claimed nearly five million people in the Democratic Congo (DRC), 1998-2002, and in carrying out and distributing humanitarian aid there.

- Failure to intervene in the 1995 Srebrenica massacre: despite the fact that the UN designated Srebrenica a 'safe haven' for refugees and assigned 600 Dutch peacekeepers to protect it, the peacekeeping force was not authorised to use force.

- Failure to successfully deliver food to starving people in Somalia; the food was instead usually seized by local warlords. A US/UN attempt to apprehend the warlords seizing these shipments resulted in the 1993 Battle of Mogadishu.

- Failure to implement the provisions of UN Security Council Resolutions 1559 and 1701 calling for disarmament of Lebanese paramilitary groups such as Fatah and Hezbollah.

- Allegations of sexual abuse by UN peacekeepers during UN peacekeeping missions in Congo, Haiti, Liberia and Sudan. (Ibid.)

These failures of the UN have been mainly in human rights and security issues and are generally ascribed to these failures coming from the UN's intergovernmental nature. As an association of 192 member states, it is, in fact, under an obligation to reach consensual decisions. It is a global international organization, but not an independent organization. Even when it reaches a decision, mandated by the 15-member Security Council, the Secretariat does not provide necessary resources to implement the decision. Inability of the Security Council to act in a clear and decisive way in a crisis and the veto power of permanent members (USA, UK, Russia, France and China) of the Security Council could also be listed as a reason for this failure.

Despite failures in some cases, the UN has some commendable success in various issues and still remains the last resort for humanity in protecting themselves from global security threats in a peaceful manner. The UN Charter envisages such a policy, which represents peaceful measures (developing UN Peacekeeping forces) to be the best device for maintaining international peace and security in a cost effective manner. According to the US Government Accountability Office:

The UN Peacekeeping is eight times less expensive than funding a US force. (Shapiro, 2012)

The main motto of the UN is 'win-win interventions' in which the intervention is based on co-operation and consent. The underlying aim of peace-keeping suggests that war is always a failure. Hence the UN being committed to peace and an enemy to war is at least a road to hope if not fully a success. Being the last resort, our present and future security depends on the UN's necessary initiatives and its continuation, for there is no legitimate alternative available to human beings other than the UN in initiating necessary global policies for ensuring humanity's present security and its continuation into the future. 
As can be observed, the crucial message of the human security view is a call for a major shift in governments' and individuals' traditional attitudes towards the issues of development and environment, for these are the issues that address essential aspects of the security issues mentioned earlier under the two heads: security from 'want' and 'fear'. The 1994 UNDP report explicitly recognizes the interdependence of security and development as the two major components of human life and dignity. This is even more apparent in the UN Secretary-General, Kofi Annan's speech in 2005:

We will not enjoy development without security, we will not enjoy security without development, and we will not enjoy either without respect for human rights. Unless all these causes are advanced, none will succeed. (Annan, 2005)

The relationship between security and development has a certain implication for their satisfactory interpretation. This relation provides the grounds for seeing 'security' as 'human security' and 'development' as 'sustainable development'. Human security offers much to the field of sustainable development. Most importantly human security underlines the 'three pillars' of sustainable development: economic sustainability, social sustainability and environmental sustainability. The urgency of the elimination of intragenerational poverty and deprivation over the short term (in addition to long term measures for eliminating intergenerational poverty) is a major reminder from human security to the proponents of sustainable development. Thus human security, for some, can be re-expressed as a comprehensive issue of 'sustainable security', which parallels the vibrant field of sustainable development. In this context Khagram, Clark and Raad write:
This more expanded field facilitates critical integrations of state, human and environment security, and parallels the three linked pillars of society, economy and nature central to the field of sustainable development. (Khagram, Clark, and Rand, 2003, p. 290)

In practice there is hardly any genuine reflection of this new understanding about human security and sustainable development. Although interrelated and interdependent, they are often considered as distinct concepts - development as a 'soft' issue and security as a 'hard' issue. (Svensson, 2007, p. 5) And this shows how deeply the traditional conception of security is favoured by state governments, and also by the majority of academia. As can be observed, my analysis suggests that a satisfactory response to security threats, particularly ones that stem from 'want' and 'fear', must involve both individuals and the state as the referents for security, and the human security view is arguably said to have developed as an enterprise directed to that end.

Recognizing the human security view as a building block of human survival, the Commission on Human Security Report 2003 maintains that:

Human security means protecting fundamental freedomsfreedoms that are the essences of life. It means protecting people from critical (severe) and pervasive (widespread) threats and situations. It means using processes that build on people's strengths and appreciations. It means creating political, social, environmental, economic, military and cultural systems that together give people the building blocks of survival, livelihood and dignity. (Commission on Human Security, 2003, p. 4)

The UN, by virtue of its position, is in the role of the key actor, undertaking security through reducing root causes by 
implementing effective measures. As it is a global international organization, not a world government, it therefore is not in a position to enforce necessary measures on nation states all over the world like those that a state government implements on its citizens. Nevertheless, making use of its position, it endeavours to guarantee the security (in the wider sense of the concept) of world humanity to a considerable extent, through planning, declaring and implementing initiatives to the best of its capacity. The Millennium Development Goals (MDGs) and the Sustainable Development Goals (SDGs) are the two major attempts of the UN to that end. All 192 United Nations member states have agreed to try to achieve these Goals. The declaration (signed in September 2000) of MDGs commits the states to:

1. halve extreme poverty and hunger;

2. achieve universal primary education;

3. promote gender equality and empower women;

4. reduce child mortality;

5. improve maternal health;

6. combat HIV/AIDS, malaria, and other diseases;

7. ensure environmental sustainability; and

8. develop a global partnership for development. (UNDP, MDGs)

Upon closer analysis the MDGs appear to be a practical initiative in addressing a range of diseases, promoting education, health and gender equality, and facilitating development and environmental sustainability.

As the Borgen Project estimates, $\$ 40$ to 60 billion each year is needed to achieve all eight goals. (The Borgen Project,
2003) It seems that the success of the elimination of the root causes of human security threats all over the world, particularly those that come from 'want' and 'fear', is largely related to the success of the UN's initiatives, namely the MDGs and SDGs since the UN is the only actor working for this. Now the question is whether it has reached its goals by the stipulated time. This attempt has been considerably successful. The progress towards the MDGs has been jeopardized largely by the 2008 economic downturn, particularly owing to diminishing resources, fewer trade opportunities and sluggish aid assistance to the developing world. Despite this barrier the story of achievements of the MDGs is not all bleak. According to the MDGs Report 2009:

-Those living in extreme poverty in the developing regions accounted for slightly more than a quarter of the developing world's population in 2005, compared to almost half in 1990.

-Major accomplishments were also made in education. In the developing world as a whole, enrolment in primary education reached 88 per cent in 2007, up from 83 per cent in 2000. And most of the progress was in regions lagging the furthest behind. In subSaharan Africa and Southern Asia, enrolment increased by 15 percentage points and 11 percentage points, respectively, from 2000 to 2007.

-Deaths of children under five declined steadily worldwide - to around 9 million in 2007, down from 12.6 million in 1990, despite population growth. Although child mortality rates remain highest in subSaharan Africa, recent survey data show remarkable improvements in key interventions that could yield major breakthroughs for children in that region in the 
years ahead. Among these interventions is the distribution of insecticide-treated bed nets to reduce the toll of malaria - a major killer of children. As a result of 'second chance' immunizations, dramatic progress is also being made in the fight against measles.

-At the global level, the world came together to achieve a 97 per cent reduction in the consumption of substances that deplete the Earth's protective ozone layer, setting a new precedent for international cooperation.

This gives an account of successes that are realized towards some selected targets. Achievements towards some other targets of the MDGs are not mentioned here, suggesting that accomplishments on those targets are significantly low, but eventually by accelerating progress it has completed its job by 2015. These successes, however, show that the goals are within reach at the global level, and even in much marginalized places. Thus, the MDGs focus on our efforts and its vision of a world 'without overwhelming human security threats' is not a nonoperational ideal standard, but an essential and viable project, which as such merits recognition. Humans' rights to freedom from security threats (especially from 'want' and 'fear') ground their moral rights, which in turn provide persuasive support for the human security view (the wider conception of security) and the justification for the UN as the legitimate and effective security actor at the global level.

Various local and regional initiatives and activities, however, can be of significant support to the UN in reaching its recently declared SDGs and other urgent pro-poor policy initiatives. Initiatives at national and regional level are needed where the nature and scope of security threats and their remedies are local and/or regional in nature. Thus, these security threats cannot be addressed without state government and regional bodies' active initiatives and participation. For example, a local and/or regional security issue may well involve a range of local security actors and systems, namely nation states' defence, police, justice, parliamentary and public security oversight, transparency in defence budgets, and respect for human rights in the exercise of their functions. (Bagayoko-Penone, 2009, p. 1) A range of academics, think tanks, and representatives of international organizations, governments, advocacy groups and NGOs are found to have agreed upon this issue. They have converged to reflect on the role of security forces and suggested that a people-centred human security perspective is needed which "links between the security system and society-at-large, focusing on threats to individuals' socio-economic and political conditions, and on communal and personal safety.” (Ibid.)

This new move suggests a comprehensive and coordinated approach to various sectors of security systems and also envisages both human security and security of states as a matter of important concern. In view of that goal, Security Sector Reform (SSR) has emerged for protecting security in a comprehensive and coordinated manner. The

purpose of SSR includes:

- enforcing both state and human security

- improving armed and security forces' efficiency by reforming their professionalism and ethics

- promoting democratic governance of the security sector, by supporting the institutions responsible for supervising security institutions (including parliaments, 
independent institutions such as ombudsmen, the media, auditors and civil society)

- developing holistic, comprehensive approaches to SSR by coordinating reforms at national and international levels

- encouraging partner country ownership (Kraft, 2009, p. 8).

SSR appears here to involve a reconciliation between the traditional states-centred approach and the human security approach. The UK has played a crucial role in formalizing the concept of SSR, and this was also endorsed by the UK Department for International Development (DFID) in 1997.

SSR has however been criticized as a non-operational concept, an ideal standard. The financial cost of reform, lack of donor coordination and coherence (with the view to reducing conflict, SSR involves donor agencies in governance), difficulties in evaluating SSR, and lack of capacities and expertise are considered as the potential challenges for the relevant states, and these are some of the main limitations of this proposed governance. Nevertheless, some proponents of SSR believe that SSR governance can bring about a significant change where commitment to democracy and human rights has become a regional aspiration. (Ibid.)

The prospects of this proposal, as I believe, depend on how nation states will line up their domestic political conditions with the democratization anticipated at national and regional level. Seemingly it is not an easy task because a state government (presumably a corrupt or a weak one) can sever their link with the regional body setting 'state sovereignty' as an excuse. Contrariwise a powerful state government can spoil the underpinning purpose of the proposed regional governance through prioritizing its own interest, ignoring the mutual interest of humankind as a whole. Thus, the prospect of SSR depends on the viability of introducing governance at regional level. This, however, needs separate study on the problems and prospects of governance, particularly regional and global governance, but there is no scope here to discuss this further.

\section{IV}

Different approaches to security have been tackled here. Overall it seems that disagreements about the concept of security take place as much within approaches to security as between them. Disagreements, at stage one, polarise related scholars into two opposing groups, involving two competing definitions of security, namely the narrow conception and the wider conception of security. Disagreements of the stage-two type are found subtler than disagreements of the stage-one type, and thus more difficult to dissolve or reconcile. Nevertheless, as we have observed, disagreements among the proponents of the stage-two type mainly concern the source of security threats (major two types of security threats, as I have discussed, are 'want' and 'fear'). Despite such disagreements, the 1994 UNDP's human security definition (i.e., the wider approach to human security) is found to be less inadequate option for the interpretation and operationalization of the concept in question. Here it is defended that the human security view is not a complete rejection of the state-centred view. The objection against the state-centred view is not because of its advocacy for the territorial defence of states, but rather for its entire omission of non-military security issues, particularly human security concerns. By justifying the UN as the legitimate actor to deal with global conflicts and security, by recognising seven interrelated significant components of human security (i.e. economic, food, health, environmental, personal, community and political), as expressed in the 1994 UNDP report, as well as recognising all bearers of intrinsic 
value as referents of security, the human security view justifies its operationalization and satisfactorily underlies the three major pillars of sustainable development: economic, social and environmental sustainability. It implies that the wider approach to security (i.e., human security view) offers much to the field of sustainable development; and the implications of the wider approach for a sustainable future are sought to be fairly similar to the implications of the standard version of sustainable development for a sustainable future, and hence mutually reinforcing. Consequently, it can well be said that it is hardly possible to attain the key objective of sustainable development, a sustainable future, while disregarding the security view in its wider sense.

\section{References}

1. Acharya, A. (2001). Human Security: East verses West, International Journal, 56: 442-460. Also available at http://hdr.undp.org/reports/global/1994/en/ [accessed 2 February 2017].

2. Albin, C. (1999). Can NGOs Enhance Effectiveness of International Negotiation? International Negotiation, 4.3: 371-387

3. Annan, K. (2005). Introduction: A Historic Opportunity in 2005 (United Nations, 2005). Available: http://www.un.org/largerfreedom/chap1.htm\# (accessed 1 February 2010].

4. Attfield, R. (2004). The Concept of Sustainable Development Revisited, Yeditepe 'de Felsefe, 1.3: 300-309

5. Axworthy, L. (2001). Introduction, in Human Security and the New Diplomacy: Protecting People, Promoting Peace, ed. by R. McRae and D. Hubert, Montreal: McGill-Queen's University Press, 2001, pp. 3-13

6. - ------. (2001). Human Security and Global Governance: Putting People First, Global Insight, 7: 19-23

7. Bagayoko-Penone, N. (2009). Promoting Peace and Democracy through Security Sector Reform, Insight, 79: 1-3

8. Commission on Human Security. (2003). Human Security Now, New York: Commission on Human Security.

9. Convention on Biological Diversity (2012). The Strategic Plan for the Convention on Biological Diversity 2011-2020, Including Aichi Biodiversity Targets, Brasilia: UNEP. Available: http://www.cbd.int/sp/ [accessed 5 May 2017].

10. Dower, N. Security in the Modern World, Aberdeen University: SDHP, Philosophy Section, (unpublished).

11. ---------.. (2005). Security and Sustainability, unpublished paper delivered at Reykjavic University, 21 October 2005

12. ---------. (1998). World Ethics: The New Agenda, Edinburgh: Edinburgh University Press.

13. Erdogan, I. (2009). Migration: As a Threat to Security? Journal of Turkish Weekly, 27 February 2009.

14. Friends of the Earth International (2009). UN Climate Conference Closes without Adopting 'Copenhagen Accord' Amsterdam: Friends of the Earth International. Available: http://www.foe.org/un-climate-conference-closes-withoutadopting-copenhagen-accord [accessed 3 February 2017].

15. Gray, J. N. (1979). John Stuart Mill: Traditional and Revisionist Interpretations, Literature of Liberty, 2.2. Available:

http://www.econlib.org/library/Essays/LtrLbrty/gryMTR1.ht $\mathrm{ml}$ [accessed 20 January 2017] 
16. Hassan, M. J. (2008). Role of Non-state Actors in International Security and on Humanitarian Issues in Conflict Areas, Kuala Lumpur: Institute of Diplomacy and Foreign Relations (IDFR) and the International Committee of the Red Cross (ICRC). Available: http://www.isis.org.my/attachments/397_MJH_RoleOfNonStateActors.pdf. [accessed 6 March 2010].

17. Hough, P. (2004). Understanding Global Security, London and New York: Routledge.

18. Human Security Centre. (2006). Human Security Report 2005: War and Peace in the 21st Century, Oxford: Oxford University Press. Available: This report is http://books.google.co.uk/books?id=rSIrNeFWIfcC\&lpg=PR $1 \& p g=P R 1 \# v=$ onepage $\& q=\& f=$ [accessed 3 February 2010]

19. Jain, P. (2006). Asian Values and Human Security: Some Definitional and Conceptual Concerns, in Annual Report 2005-2006: Human Security, Kobe: Asia Pacific Research Centre, 2006: 338-346

20. Khagram, S., Clark W. C., and Raad, D. F. (2003). From the Environment and Human Security to Sustainable Development, Journal of Human Development, 4.2: 289-313

21. Kraft, H. J. S. (2009). Democratisation and Reform in SouthEast Asia, Insight, 79.

22. Lizée, P. P. (2006). Human Security in Vietnam, Laos, and Cambodia, in Contemporary Southeast Asia, quoted in Levine, S., Human Security and 'Asian Values', in Annual Report 2005-2006: Human Security, Kobe: Asia Pacific Research Centre: 347-374

23. Nef, J. (1999). Human Security and Mutual Vulnerability, Ottawa: The International Development Research Centre.

24. Paris, R. (2001). Human Security: Paradigm Shift or Hot Air, International Security, 26.2: 87-102
25. Reed, L. and Tehranian, M. (1999). Evolving Security Regimes, in Worlds Apart: Human Security and Global Governance, ed. by Tehranian, M., London: Taurus, 1999: 54-78

26. Rolston, H. III (1998). Environmental Ethics: Duties to and Values for Natural World, Philadelphia: Temple University Press.

27. Shapiro, A. J. (2012). The Global Peace Operations Initiative, Washington, DC: The U.S. Institute of Peace. Available: http://www.state.gov/ /pm/rls/rm/ 84845htm [accessed 10 April 2017].

28. Smith, K. E. (2003). European Union Foreign Policy in a Changing World, Cambridge: Polity Press.

29. Svensson, K. (2007). Human Security as Inclusive Security-Gender, Epistemology and Equality, African Security Review, 6.2: 2-13.

30. The Borgen Project. (2003). UN Millennium Development Goals, Dutch Harbor, Alaska: The Borgen Project. http://borgenproject.org/un-millennium-development-goals/ [accessed 3 February 2017]

31. Thomas, C. (1999). Introduction, in Globalization, Human Security, and The African Experience, ed. by Thomas, C., and Wilkin, P., Boulder: Lynne Rienner Publications: 1-19

32. Towards a Synergy of the Two Regimes? (2002). Review of European Community \& International Environmental Law (RECIEL), 11.2:169-180. Also available at: http://dx.doi.org/10.1111/1467-9388.00315

33. United Nations (1986). Declaration on the Right to Development, New York: United Nations.

34. United Nations, Charter of the United Nations, Available: http://www.mfa.gov.tr/data/Kutuphane/MultilateralConventi ons/CharteroftheUnitedNations.pdf [accessed 5 May 2017]. 
35. United Nations (2009). The Millennium Development Goals Report 2009, New York: United Nations. Available: http://www.un.org/millenniumgoals/pdf/MDG_Report_2009 ENG.pdf [accessed 2 February 2017]

36. United Nations Development Programme. (1994). Human Development Report, 1994, New York: Oxford University Press.

37. United Nations Development Programme, Millennium Development Goals (MDGs), Available at: http://www.un.org/millenniumgoals/ [accessed 2 February, 2017).

38. World Commission on Environment and Development. (1987). Our Common Future, Oxford: Oxford University Press.

39. XTimeline. (2008). United Nations: Its History and Milestones, Available: http://www.xtimeline.com/timeline/United-Nations--ItsHistory-and-Milestones [accessed 11 February 2017].

\section{Endnotes}

${ }^{1}$ Realists are the traditionalists in International Relations and Security Studies who focus their enquiries on military security in inter-state relations, envisaging states as the main 'actors' in security discourse. In philosophy, however, there are two schools of realism, namely metaphysical and epistemological; and philosophers who belong to relevant groups are recognised as realists in this sense. The word 'realist' has been used here to mean entirely different people, i.e. scholars of International Relations, not philosophers.

${ }^{2}$ Aldo Leopold is the pioneer of this concept.

${ }^{3}$ United Nations, Declaration on the Right to Development, (New York: United Nations, 1986), Preamble, Paragraph 2.

${ }^{4}$ Friends of the Earth International, UN Climate Conference Closes without Adopting 'Copenhagen Accord' (Amsterdam: Friends of the Earth
International, 2009) http://www.foe.org/un-climate-conference-closeswithout-adopting-copenhagen-accord [accessed 3 February 2017]. Full text of the 'Copenhagen Accord' can be accessed at http://www.guardian.co.uk/environment/2009/dec/21/copenhagen-accordclimate-change.

${ }^{5}$ For instance, Fréderic Jacquemont and Alejandro Caparros argue that cooperative impact of UNFCCC and the CBD appears to be complementary although in effect they are not. This conflicting situation arises particularly whilst agreements to the UN Framework Convention on Climate Change (UNFCCC) are implemented in accordance with the policy guidelines set by the Kyoto Protocol. It is because, as regards forestry, the Kyoto Protocol promotes the use of forests as sinks in order to reduce greenhouse gas (GHG) emissions to 5\% below 1990 levels. According to Fréderic Jacquemont and Alejandro Caparros, co-operative efforts (which have recently begun) between the UNFCCC and the CBD are in place in order to attain the specified target of GHG reduction, but co-operative efforts tend to convert an old forest into a single species forest, which have potential negative impacts on biological diversity. For Fréderic Jacquemont and Alejandro Caparros, an integrated harmonized ecosystem approach is needed that makes a balance between harmonized and coordinated biodiversity concerns and GHG mitigation. For details see Jacquemont F., and Caparrós, A., 'The Convention on Biological Diversity and the Climate Change Convention 10 Years After Rio: Towards a Synergy of the Two Regimes?', Review of European Community \& International Environmental Law (RECIEL), 11.2 (2002), 169-180. This article is also available at http://dx.doi.org/10.1111/1467-9388.00315 